\title{
The Role of Animals in Eco-functional Intensification of Organic Agriculture
}

\author{
Mette Vaarst $^{1}$ \\ ${ }^{1}$ Department of Animal Science, Aarhus University, Research Centre Foulum, P. O. Box 50, 8830 Tjele, Denmark \\ Correspondence: Mette Vaarst, Department of Animal Science, Aarhus University, Research Centre Foulum, P. \\ O. Box 50, 8830 Tjele, Denmark. Tel: 45-2290-1344. E-mail: Mette.Vaarst@icrofs.org
}

Received: February 22, 2015 Accepted: May 4, 2015 Online Published: June 20, 2015

doi:10.5539/sar.v4n3p103 URL: http://dx.doi.org/10.5539/sar.v4n3p103

\begin{abstract}
Eco-functional intensification is understood as building synergies in multi-functional and resilient agricultural systems in harmony with their surrounding environment and human systems, to the benefit of diversified production of food and beyond, as in, for example, ecosystem services. Integration of animals into eco-functionally intensified agricultural systems to enhance agricultural, ecological and social systems, can contribute to driving a future sustainable development of organic agricultural and food systems. This approach may respond to challenges of an increasing industrialization of livestock in the global north, a process which has led to heavy reliance on external inputs, and, to a large extent, a detachment of animals from farming systems, especially in the global south. Animals are living sentient beings, but often not acknowledged as such. Complex, well-integrated systems can be organized so that they support the health and welfare of animals, and let these animals be valuable resources within the farming system. There must be an emphasis on diverse genetic inheritance and locally adapted species. Complex systems require complex knowledge which must be continuously developed to respond to current challenges in constantly changing environments, e.g., climate change. A necessary driver in transition towards more eco-functionally intensified agricultural and food systems is a governance system which protect the actors without a voice, e.g., ecosystems, pollinators, animals, and future generations through regulation of consumption patterns, flow of external inputs, and resource use. This requires a change in attitudes both acknowledgment of the importance of protecting the environment, consumption, resource use; and seeing agricultural systems as necessary and valuable contributors to nourishing both people and the earth.
\end{abstract}

Keywords: livestock, governance, agricultural systems, ecological intensification

\section{Introduction}

\subsection{The Idea of Eco-Functional Intensification (EFI)}

Intensification of agriculture is often understood as 'increasing the input intensive aspects of the agricultural systems to get a high output of a certain commodity', using more energy, nutrients and water but less labor input. Gamborg and Sandøe (2005) describe for example how animals have been bred to grow faster and produce more leading to a range of production based welfare problems, and as a part of intensification of agriculture since 1950s. Eco-functional intensification is quite different from this. There is no published and universally accepted definition of 'EFI'; however, Niggli et al. (2008) presented it as:

'first and foremost, activating more knowledge and achieving a higher degree of organization per land unit. It intensifies the beneficial effects of ecosystem functions including biodiversity, soil fertility and homeostasis. It uses the self-regulatory mechanisms of organisms and of biological or organizational systems in a highly intensive way. It closes material cycles in order to minimize losses (e.g. compost and manure). It searches for the best match between environmental variation and the genetic variability of plants and livestock'.

This will mean a higher degree of diversification within the system. Eco-functional intensification also increases the complexity of systems, utilizing the genetic variability and other resources and introducing clever use of low or no risk technologies. Eco-functional intensification of a system must happen in harmony with the surrounding nature, and in such a way that all resources involved are utilized and maximized within the system, irrespective of the scale we talk about. Eco-functional intensification of a given agricultural system is knowledge intensive in 
terms of contextually relevant knowledge. By increasing the complexity of a system, building on the synergistic effects among components and/or between levels within the system, one could claim that the full system appears 'simpler' because self-regulating mechanisms, as well as a number of mutual systems effects, are enhanced. On the other side, it requires immense knowledge and insight, which can be facilitated though communication and local community-based and context-specific knowledge generation.

Eco-functional intensification will in many ways stress the organic principles described by the International Federation of Organic Agriculture Movements - IFOAM (IFOAM, 2005), where the principle of ecology states that: "Those who produce, process, trade, or consume organic products should protect and benefit the common environment including landscapes, climate, habitats, biodiversity, air and water." This requires systems approaches which are beyond many organic agriculture regulations. Organic regulations are generally concerned with how a production takes place, for example ensuring that chemical fertilizers and pesticides are not involved, but not requiring a certain way of organizing the system in terms of diversification.

Intensification towards more diversification can go beyond the agricultural system itself. Ideally, an agricultural system interacts with human, social and ecological systems in synergetic ways. Vanlauwe and co-authors (2014) used the example of sustainable intensification (SI), which in their paper was viewed as achievable only if diversity in agro-ecological conditions, farm household endowment, farming systems, and socio-economic conditions within the landscape were taken into account.

Eco-functional intensification can for example consider pollinators such as bees, which bridge the natural system with the agricultural system. This can include both wild bees ('ecosystem service'), and domesticated farm animals, Apis mellifica. Tcharntke and co-authors (2012) argue for such land-sharing approaches, where agro-ecological intensification is the backbone for global food security, by, among other things, involving and inviting crucial ecosystem services as part of what they call 'planned and associated biodiversity', to benefit the agricultural system.

Another side of intensification is the interaction between human and social systems and farm animals within the framework of an agricultural system. An example of this is a system where animals' 'natural needs' are met by allowing animal mothers to interact with their offspring during the milk feeding period. Such system requires in-depth insight into animals' needs, behavioral patterns, health and welfare issues, as well as experience when observing and 'reading' animal signals. Furthermore, all this has to be a part of a wider system into which multiple functions of the farm also fit, in a knowledge intensive innovative system.

Finally, it can also be claimed that the idea of EFI plans for resilience by spreading risk over more elements in the production. This is in contrast to industrial intensification, which aims at a high yield of a commodity, often measured by man hours invested in the production. In other words, the idea of 'EFI' has wide perspectives, and animals can be involved in agricultural systems and can interact with their various components in multiple ways.

\subsection{Rethinking the Notion of Performance in Food Producing Systems with Animals}

In food production, 'performance' is often referred to as high yield. When considering EFI, it is relevant to consider other qualities related to performance, which does not necessarily exclude 'high yield', but merely encompasses a more holistic understanding of how animals can perform in the system. Highly diverse agricultural systems will include production of other things than tangible animal products (Tichit et al., 2011), such as eco-system improvements like improvement of soil, air, clean water, or biodiversity. When animals are well integrated into such systems, their performance can be described as 'systems contributors'. These systems contributors manage land in a way which maximizes the synergy between the animals and different plants. For example, letting animals root on post-harvest-areas, contributes to agro-forestry systems, as with fruit and other food trees with poultry raising, or contributing to integrated or mixed land use e.g., in rotations.

Organic animal farming should ideally build on ecological systems with closed nutrient cycles. An eco-functionally integrated animal farming system will not rely on high amounts of external inputs. On the contrary, the characteristics of the system will be determined by what is possible within the boundaries of a self-reliant system. As a mirror to the considerations related to planetary boundaries (as described by Röckstrom et al., 2011) it can be relevant to examine "which local system boundaries do we need to respect and build on to avoid trespassing planetary boundaries'? In the following, I will briefly examine some of the challenges of current organic livestock production systems, and use this to discuss relevant aims of an eco-functional integration process of organic animal farming. 


\section{The Setting: Challenges of Current Organic Livestock Production}

Organic animal production is growing in some countries, and an increasing number of consumers choose organic animal products (Anonymous, 2014; Willer \& Lenoud, 2015). At the same time, organic agriculture is also challenged by being part of a global, conventional food system in many parts of the world. The current global food system is operated by relatively few major corporations, produces huge amount of waste through the way in which it is organized, and, in many cases creates complete separation between producer and consumer. This is very far from the principles of organic agriculture, such as the closed nutrient cycles and the ideas of fairness. Organic animal based food products are basically competing on the same premises as all other food which is industrially produced, transported, packaged, stored, and processed in big quantities. In some cases, it stimulates consumption patterns which can also be questioned in terms of sustainability, for example 'organic fast food', and a generally high consumption of livestock products, some of which are not produced in well-balanced, integrated agricultural systems. In general, one can claim that the sustainability of any farming system can be questioned when it is part of an unsustainable food system (Vaarst et al., 2015).

In a discussion about how EFI of organic agriculture can help further development of organic animal agriculture towards a higher degree of sustainability in all its aspects, it is important to address the current challenges facing much organic agriculture. In the following, both the global north and south will be considered.

\subsection{Challenges in the Global North}

\subsubsection{A Livestock Industry Relying on Multiple Inputs}

Three types of inputs are especially relevant as inputs on which organic livestock production in the global north, especially in Europe, relies: imported feed, fossil fuels, and antibiotics.

One important thing that happened in the industrial agriculture was a more or less complete detachment between animals and land, promoted by introduction of feed which could be transported over large distances, e.g. from Brazil or China to Europe. This possibility of transporting both feed and live animals moved agriculture from being oriented towards systems designs and recycling of resources, being self-sufficient (on a certain scale ranging from farm to regional levels) towards a commodity-oriented production, allowing huge amounts of one product to be produced in specialized areas, and allowing a huge animal production in places requiring feed transportation, with animal products subsequently transported away from the production site. An estimated $34 \%$ of current global cereal production goes to animal feed (FAO, 2013), whilst livestock takes up to $70 \%$ of all agricultural land (Steinfeld, 2006). Ideally, manure is a valuable resource, and yet, it is often referred to as a source of pollution, in areas with a dense livestock population. Consequently, feed is transported into some areas and manure is transported out of the same areas, as a sign of a complete detachment between animals and land.

Organic farming should ideally be based on closed nutrient cycles, which means that feed should primarily be of local origin. The notion of 'local origin' of feed can be questioned: in some contexts it is understood as feed from the same farm on which animals live, as for example, when the Danish organic farmer organization included in their requirements that $50 \%$ of the feed should be produced on the farm or in cooperation with other farmers within a radius of $25 \mathrm{~km}$ (Mogensen, 2004). In other contexts it is understood as feed produced within a regional area, or wider, e.g., in the European research project ICOPP it was defined as 'European feed' (http://www.organicresearchcentre.com/icopp/). However, 'local' should not be understood as feed brought over long distances. Some ingredients for organic concentrate feed are imported to USA and Europe, e.g. Chinese organic soy bean. This furthermore illustrates the detachment between land and animal production, on which huge parts of today's industrial agriculture is based, and which organic production should ideally not apply to. According to FAO, livestock production accounts for about a third of the global cropland production, and livestock production is increasingly managed in large-scale operations and involved in international trade (http://www.fao.org/ag/againfo/themes/en/animal_production.html; retrieved 21 $1^{\text {st }}$ Feb.2015). Schader et al. (2013) modelled the environmental impact of livestock in five different future scenarios, and compared among others the scenario of 'upscaling organic agriculture' (in its current form) versus 'banning concentrate feed', and found that the latter would be more environmentally friendly than upscaling organic agriculture in its current form. This could indicate that the ideas of EFI of organic agriculture with animals, is highly relevant. The use of freshwater is strongly connected to the land-use of livestock production. Livestock production accounts for about $20 \%$ of the world's freshwater use (Molden et al., 2010). Out of this, only $2 \%$ is estimated to go to their actual drinking, and the rest to the feed production (Peden et al., 2007). Depending on the type of production, freshwater is involved in other processes than feed production, such as washing of milking parlors and cooling of milk, in the dairy sector. 
The issue of import and export of organic feed furthermore relates to the current reliance on fossil fuels, which is heavily involved in all aspects of organic animal production, from the on-farm feed production and transport, through farm operations using machinery and electricity to the transport of products. Tittonell (2013) gave the example of maize grains, where $70 \%$ of the energy comes from fossil fuels, and calls it the 'intensification trap' because it creates dependency. Processing units are getting bigger and fewer, which means that milk, eggs and all other animal products, as well as live animals, must be transported over longer distances, sometimes between countries or even continents.

Whilst a complete prohibition of antibiotics exists in organic agriculture in the USA, it is permitted in Europe for treatment of diseases, and can only be administered by a veterinarian, or through the involvement of the veterinarian in one way or the other. The actual use of antibiotics varies extremely between sectors, countries, and even farms. Access to and availability of alternatives to antibiotics is quite high in parts of the USA and is relatively well spread among organic farmers, involving various ways of using them, and different results. In the EU (European Union) countries, legislation has almost blocked any use of for example homoeopathy, and partly also of phytotherapy. However, in many European countries, organic farmers have been leading in building up and ensuring animal health promoting strategies for organic livestock, which have led to significant reduction of antibiotic use in organic dairy cattle, in particular (Bennedsgaard et al., 2010; Ivemeyer et al., 2012 \& 2015). Nevertheless, European organic animal farming has the possibility of treatment with antibiotics as a constant 'back-stopper', which still can be regarded as 'reliance' in many cases, because it potentially influences the whole herd management strategy.

\subsubsection{Loss of Agro-Biodiversity and Genetic Inheritance}

Humankind has domesticated at least 30 species of farm animals, accounting for over 8.000 registered breeds, of which many are locally adapted, multi-purpose and indigenous. Large parts of North European organic farming are single commodity-oriented and mono-cultural, that is, in the case of livestock production, farms with only one animal species, often with no other type of production than animal production and feed for the animals. The number of different breeds available for organic agriculture has become very low over the last decades particularly, in certain countries. The current breeds in industrial systems of today are almost exclusively single purpose breeds. For example, in today's broiler production, the very few existing genotypes are selected for excessive growth and very high feed efficiency, but they are more vulnerable in terms of immune competences (Rauw et al., 1998). Eradicating breeds means not only losing natural capital or 'wealth' in a colorful and diverse world, but also eradicating possibilities for adaptation to different environments and situations, e.g., climate changes or consumer choices (FAO, 2014).

In other words, the underlying systems theory and approach of organic agriculture is not met in practice in large parts of organic animal farming today. The emphasis on specialisation can have potential impact on the way in which we focus our breeding and our perception of which animal types are needed. When animals are viewed not as systems components with potentials for interaction with other elements within the system, but as 'the production focus on the farm', animals are bred and shaped to fit into these 'high production systems'. Poultry production represents one extreme of this, where layer hens and broilers are completely 'separated' by breed, meaning that millions of male chickens of layer hens are killed just after hatching, which can raise severe ethical concerns, and which is not in accordance with organic or ecological ways of thinking. The low degree of diversification within-farms can influence breeding aims and patterns, and vice versa.

\subsection{Challenges in the Global South}

Livestock contributes to the ecological and environmental sustainability of many tropical smallholder farming systems, e.g., in nutrient recycling (Hermansen, 2003; Powell et al., 2004). Livestock play a significant role in household food and income (Dreschemaeker et al., 2010; Funes-Monzote, 2008). Besides, they provide with many other materials. Tropical smallholder livestock keepers represent about $20 \%$ of the world population (McDermott et al., 2010).

\subsubsection{Livestock Not Fully Included in the Idea of 'Organic'}

Even though many smallholder farming systems in the global south are diversified, and some of them use agro-ecological practices, they are not considered 'organic'. 'Organic agriculture' is defined as organically certified in accordance with the organic standards of global north countries, and with the focus on producing organic high-value products (for example coffee, cocoa, spices, herbs and fruits). Most organic products are for export to countries in the global north, where approx. $95 \%$ of the global organic production is sold. In many cases, animals are part of the farms on which export products (for example vanilla or pineapples) are produced, but they are not thought of as 'organic', because their products only very rarely can be sold as organic. Odhong 
et al. (2014) and Nalubwama et al. (2014a \& b) emphasized how the livestock herd and the farm seem to 'co-exist' but not as a fully integrated farming system. Many organic standards are not fully developed, for example the organic feeding standard (Kiggundu et al., 2015).

\subsubsection{Utilizing Manure Efficiently Versus Letting Animals Meet Their Natural Needs}

In many tropical smallholder farms, there is a need for arable land and manure. At the same time, the organic principles emphasize that animals should meet their natural needs. This is identified as a major dilemma in organic smallholder farms with scarce land in the tropics (Muwanga, 2010). The manure is needed for compost or other redistribution of nutrients, and at the same time, land is very scarce and must provide food for a whole family and in some cases also for cash crops. In many tropical smallholder farming systems with animals, the change from traditional farming to organic and agro-ecological farming has led to keeping animals indoors to a much higher degree because of new awareness of the value of manure (Muwanga et al., 2010). Araya and Edwards (2006) and Edwards et al. (2010) illustrate this well in their work, showing how severe land degradation problems in arid areas in Ethiopia were solved mainly by creating zero-grazing systems for the small ruminants in the area. This restricted the animals from grazing, and thereby many aspects of natural behavior while foraging, performing social behavior and moving around on grassland.

\subsubsection{Endemic Diseases}

Endemic diseases are a major challenge in many tropical countries in the global south (Rubaire-Akiiki et al., 2006; Vaarst et al., 2006). Rubaire-Akiiki et al. (2006) concluded that in the case of local and cross-bred cattle, most tick-borne diseases could be managed by regular hand-picking of ticks. This is not possible with so-called exotic cattle (e.g. Holstein-Friesians) which are much more vulnerable to infections (Rubaire-Akiiki, personal communication, 2014). In pastoralist herds with hundreds of cattle, this is obviously not possible. These animals are given the possibility of carrying out their natural grazing behavior and, depending on the climate and environment, they will get sufficient amounts of feed in accordance with their natural needs. However, they are in higher risk of endemic diseases, hence also of the use of acaricides and other medicines, especially when land areas are restricted, and they are exposed to ticks and other vectors. In the case of poultry, free-ranging life can be very challenging as well, and vaccinations can be one option, e.g., to overcome Newcastle disease in free ranging poultry.

\section{Roles of Animals in Eco-Intensified Agricultural Systems}

When researching and discussing the potential roles of animals in well integrated and eco-functionally intensified farms, it is relevant to see this both from the side of the animals and from the perspective of the systems. This will be done in the following, where I open up for a view on livestock as animals, and thus for a wider systems approach to 'animals'. However, this article is primarily focusing on the role of farmed animals in EFI of organic agriculture. The second section of this part of the article will be the systems view on integrating animals into the system, including examples and case studies.

\subsection{Meeting Livestock's Common Global Challenge: They Are Animals}

Various definitions of livestock exist. According to the Codex Alimentarius, livestock means 'any domestic or domesticated animal including bovine, ovine, porcine, caprine, equine, poultry and bees raised for food or in the production of food. The products of hunting or fishing of wild animals shall not be considered part of this definition' (Awada, 2011; http://www.fao.org/docrep/005/y2772e/y2772e04.htm). Others define it differently, for example the online dictionary Merriam-Webster (http://www.meriam-webster.com/dictionary/livestock) explicitly excludes poultry. FAO defines it broadly: "The terms "livestock" and "poultry" are used in a very broad sense, covering all domestic animals irrespective of their age and location or the purpose of their breeding. Non-domestic animals are excluded from the terms unless they are kept or raised in captivity, in or outside agricultural holdings, including holdings without land' (FAO, 2011). The differences as well as the combination of these definitions may reflect a view which is very valid or even necessary to consider in the case of organic farming: the organic well-integrated farming system builds on mutual benefits and synergies between 'the system' and 'the animals', and this can include both domestic or wild animals, such as pollinators, earthworms, wild birds and mammals.

Animals have many different roles in human lives, as working partners and providers of multiple products like eggs, milk, wool, skin, bones, meat, honey and manure, just to mention some. They bear many cultural meanings, they are part of our history and have been domesticated and shaped and have helped us shaping our lives. In integrated agricultural systems they are systems partners: they are important partners in the nutrient cycle, interact with the soil (for example by stepping on and rooting in it, and providing it with nutrients), and with the 
surrounding nature if allowed, by, for example, choosing certain elements of the vegetation, browse trees and interact with the birds and other wild fauna. So, we can identify many ways in which animals are integrated into whole systems and interact both with the human and the ecological systems. According to its principles, organic farming incorporates a systemic view of humans and animals as part of the surrounding larger ecological system (Alrøe et al., 2001; Baars et al., 2004; Vaarst et al., 2004a). Animal health can be described within the framework of resilience (Döring et al., 2013), and the system of which animals are part, should be organized in ways which enable them to unfold as individuals and use their capabilities as part of their welfare (Cabaret et al., 2014). Animals are living sentient beings, which can feel pain, anxiety, happiness, frustration and fear. They are domesticated, but also have what can be characterized as 'natural needs', a characterization which is not only about their behavioral patterns, but equally about their need for species-specific feed. The organic principles as formulated by IFOAM acknowledge this aspect and emphasize in many ways the role of animals as partners in the system (the principle of ecology). However, the concept of naturalness is also included here. For the animals, this includes access to outdoor areas and freedom of choice that allows each animal to express its individual preferences (Lund, 2002, 2006; Verhoog et al., 2004; Verhoog et al., 2007; Waiblinger et al., 2004; Bracke \& Spoolder, 2013). Their species specific needs can, for example, be having mother-offspring contact, dust bathing, space for natural laying down behavior, wallowing, grazing and social behavior), and to have species-specific feed, so that ruminants are fed 'ruminant feed', which is high amounts of roughage and grass based diets.

Lund and Olsson (2006) described animal agriculture as a form of living together between humans and animals that has evolved through a process over thousands of years. Lund (2002) and Lund et al. (2004) discussed the "ethical contract" between humans and farm animals in organic farming, farmed according to the organic principles. Humans have a moral obligation to take care of the animals for which they have taken responsibility. This care includes allowing them access to as much naturalness as is possible under farmed conditions, and caring for them at all times. An aspect of this care is to intervene when necessary. According to the ethical contract, humans are allowed to use animal products and take animals' lives, but they have the obligation to ensure that the animals in human households live a life in which they are allowed naturalness, and where they are taken care of when needed. Both "naturalness" and "care when needed" are vaguely expressed and seem unavoidably left to negotiation in practice (Vaarst et al., 2004b). Numerous 'animal welfare assessment models' have been developed, based on different views on animal welfare (Haynes, 2013; Fraser, 2010), and can provide a well-informed basis for discussion and negotiation about the animal welfare situation in a given herd. However, a negotiation about the understanding of animal welfare and the situation on a given farm will be based on individual perceptions and ethical choices, depending on humans' knowledge, insight, empathy, ability and willingness to relate to the animals and their needs (Vaarst et al., 2004b). According to Hendrickson and James (2005), group and self-identity are prime movers for ethical or moral behavior. They explained how a changing environment towards industrial farming can lead to what they call "erosion of farmer ethics", with severe structural and practical consequences for the way the farm is designed and organized, and the animals are managed. Organic agricultural systems must necessarily include care for and management of animals, as a part of thinking them into whole farming systems. Appleby (2005) formulated 'A collaborative approach to humane sustainable agriculture will benefit animals, people and the environment'.

Changing focus from 'livestock' to 'animals' may lead the attention to also caring for and integrating non-domesticated animals into the farm. It can be argued that this is very much in accordance with the idea of a fully eco-functionally integrated farm, where, for example, animals categorized as so-called ecosystem service animals, such as earthworms and wild pollinators, are highly valued as components of the farm. Other animals, such as birds and wild mammals, can also have roles to the benefit for the whole agricultural system in its interaction with the surrounding nature.

\subsection{Animals as Integrated Partners in Diversified Systems}

The integration of domesticated animals into farming systems can give long term benefits in terms of circulation of nutrients, utilization and care of land areas, prevention of land degradation and erosion, and contribution to resilient and robust, diversified, and intensified farming systems (Funes-Monzote, 2008; Pretty, 2006; Halberg et al., 2009; Vaarst, 2010). To enable this, a balance between the capacity of the land area, the species, and the number of animals is paramount. Different animal species clearly contribute differently to the system. Bonaudo and co-authors (2014) emphasized how cattle in a moderate stocking rate and with a moderate milk production, could benefit the system in more ways by letting grass be the main fodder source reducing bought-in-feed. The photosynthetic capacities of the grasses optimize the conversion of carbon dioxide, water and minerals into biomass. Legumes fix nitrogen, and there is a synergy within the mixture of legumes and grasses. The cows harvest, fertilize and weed the field, fulfilling in this way at least three functions, and attempting to have a long 
grazing season cuts harvesting and distribution costs (Bonaudo et al., 2014). In many ways, this type of system is not a 'new invention' - rather a traditional cattle rotation system. Nevertheless, such a system represents an alternative to industrial cattle systems, and can furthermore include use of marginal land, which then contribute to the production of animal products. These systems can also help create farm areas where pollinators, earthworms and wild animals can find space. In many settings, dairy production is quite mono-cultural, but there are huge potentials that dairy cattle can be drivers and be part of a farm which follows a diversification strategy. Monogastric animals are often perceived as more challenging than ruminants. However, poultry fit into many different agro-forestry systems, where they keep away pest animals from fruits and berries, and benefit from the shelter and protection given by the vegetation (Pedersen et al., 2004). Synergy effects have been shown in farms with pigs working on land after harvest, or e.g. energy crops or Jerusalem artichokes (Kongsted et al., 2013). Integration of more animal species on a farm requires much human insight. The development over the past decades has gone more and more in the opposite direction, that is, towards specialization, monoculture and increased herd sizes on farms. This might explain why it is difficult to find recent research documenting benefits for animal health and welfare of multi-species animal integration in agricultural systems in the EU or the U.S., although a lot of recent and current projects also look at integrated production, for example the EU-funded projects Agforward (http://www.agforward.eu/index.php/en/) investigating different viable agroforestry strategies, and and 'CANtogether' (http://www.fp7cantogether.eu/index.php). Gliessman (2006) pointed to animals' role in shaping landscapes, ensuring energy flows and influencing the dynamics of plant population and species interaction. Bonaudo et al. (2014) analysed and discussed agro-ecological practices in a French and in an Amazonian system which shifted from systems with co-existence of crops and animals, to an integrated crop-livestock system, meaning that they created or re-created links between soil crops and animals through a diversified production, with the additional benefit of giving economic resilience to market shocks. They maximized ecological (predator-prey) or production-based interactions, e.g., by improving complementarities between production cycles. These systems illustrated how elements of agro-ecological practices under two widely different sets of conditions, could contribute to robust and viable systems, and led to the conclusion that there are several paths to building more and more sustainable systems. In practice, they minimized losses and external inputs, optimized the nutrient availability for crops and animals through temporal management, and developed the collective management at the landscape level, including the semi-natural elements (Bonaudo et al., 2014).

Animals which are integrated into complex agro-ecological farming systems constitute a part of this system with its synergies and mutual benefits. Silvopastoral agroforestry systems seem to form one particularly promising approach to integrated systems throughout climatic zones, which is still relatively unexplored and unexploited in industrialised countries and the special conditions of temperate climatic zones.

\section{Strengthening Systems Approach and Eco-Functional Integration in Animal Systems}

Agricultural systems which benefit animals, humans and ecosystems, must necessarily be based on balance and connection between land, water, resources, humans and animals within the farming system. This will mean building up diversified systems, which are resilient in an ecological sense (different elements of the system supporting each other and creating buffers to shocks and events) and economic sense (for example risk diversification). An emphasis on complexity and diversification within agricultural systems will lead to a more diversified local production of food and other products, which can be mutually related to reduction of fossil-fuel-based transport. Diversified agricultural systems producing food for more local food systems will require e.g. a more seasonal food pattern, which is just one step towards fundamental changes in current consumptions patterns and food systems. Other changes will be efforts towards less food waste and lower consumption of animal products. This calls for an improved governance of agricultural systems. Moraine et al. (2014) emphasized the need for keeping flexible public policies to meet increased demands for preserving common assets in agricultural areas, rather than trying to meet the economic competitiveness of the agricultural sector. Hilimare (2013) reviewed possibilities for crop-livestock integration in North America, and mention the challenge of having regulatory frameworks which are better suited for large-scale farms. This is just some examples of regulations encouraging one type of farm enterprise, namely the more industrial model. All these issues of governance and institutional changes around our food systems are beyond the scope of this article, although closely connected in the call for a profound transformation of farming and food systems towards an eco-functional integration of human, social, institutional, ecological and agricultural aspects and systems elements.

Such an emphasis of larger agricultural systems can take different forms. Lemaire and co-authors (2014) emphasized the urgency of forming diversified, resilient systems and suggest that even if farms specialize, the 
collaboration and integration between farms in an area can form a coherent and large-scale ecologically intensified system. Moraine et al. (2014) presented and discussed collaboration between farms to create integrated crop-livestock farms in a European project 'CANTOGETHER' (http://ec.europa.eu/research/bioeconomy/agriculture/projects/cantogether_en.htm), and identified basically four different types or 'scales' of integration between farms, from exchange (type 1) to 'increased temporal and spatial interaction among the three spheres in a rationale of territory-level synergy', where it is organized so that resource allocation, knowledge sharing, and work as well as other types of collaboration is optimized (type 4). Based on three contrasting cases, they identified some common trends: all three cases were characterized by a certain level of diversity, either on cropland use, production systems or landscape. Grassland, cash crops and forage crops were present in all cases, and ecosystem service improvements could be identified in all cases, and obviously, all cases had some level of collaboration, sharing and development of social systems between involved farms and families, as well as in relation to the surrounding society.

Dumont et al. (2014) outlined different strategies to incorporate agro-ecological strategies to integrate crop and livestock systems better, among others adopt management strategies aiming at improving animal health (e.g. different plants strengthening immunity, preventing disease and giving better nutrition). The monogastric animals are particularly challenging to integrate, and strategies to reduce inputs and pollution are important in the process of eco-functional integration. Ruminants in particular have the ability to use roughage from areas where no food for potential human consumption can be grown and by-products which are not suitable for human consumption. An integrated system will use this ability and reduce competition between humans and animals regarding resources, including feed/food production.

It is well documented that even though farming according to the organic standards provide a framework which is more animal-friendly than industrial farming, it does not ensure that the practices live fully up to the organic principles, nor does it guarantee good animal welfare (Sundrum et al., 2006; Vaarst et al., 2008). In the process of creating systems that meet animals' needs, much knowledge and the ability to reflect and innovate is required. For example when managing organic calves, organic farmers need knowledge about disease risks and epidemiology as well as knowledge of ethology and natural behavior to design systems and act in these systems in ways that are appropriate to the animals that we have domesticated and taken into human care (Vaarst et al., 2001, 2004b), and they have to have the ability and willingness to develop such systems in their own farm context. When intensifying the systems towards better integrated ecological systems, learning and knowledge generation has to take place, and innovation is crucial for this process. We are often restricted to think of innovations only as technical solutions. A Danish action research project in collaboration between the Thise Dairy Company and Organic Denmark and Danish Institute of Agricultural Sciences (now merged into Aarhus University) developed the so-called 'stable schools', which employ a farmer owned, facilitated advisory method in farmer groups (Vaarst, 2007; Vaarst et al., 2007). This concept was developed in European projects to different farm and advisory contexts, and demonstrated the importance of farmer ownership in development of farm practices for lasting change on herd and farm levels (Vaarst, 2007; Ivemeyer et al., 2012, 2015; Vaarst et al., 2010, 2011a, 2011b; Bennedsgaard et al., 2010). MacMillan and Bennett (2014) involved farmers in innovation and research processes with interesting results. Padel and co-authors (2015) emphasized that it is important to think of innovation in terms of, for example, social or environmental innovation, where clever and context relevant solutions are developed for the organization of social systems-for example, farmers working together in new ways, or in new combinations of plants or ways of processing farm products.

Niggli et al. (2008) emphasized the importance of knowledge for the process of EFI in a vision paper for research in organic agriculture (see above): 'Knowledge is the key characteristic of eco-functional intensification'. Approaches like Stable Schools or Farmer Field Labs as described above, could offer interesting approaches to common knowledge generation for further development of eco-functionally integrated agriculture. Similarly, a new mode of thinking in new ways is needed for scientific development. Tittonell (2013) urged the development of new scientific approaches to whole-farming systems analyses. Gonzales-Garcia and co-authors (2012) explained how complex multi-functional systems require research which includes the complexity and meets it with multidisciplinary and holistic approaches. In the same line of thinking, Moraine et al. (2014) proposed that multilevel and multi-disciplinary designs of research projects are developed to fully understand the ability of agro-ecology to enhance ecological processes as well as of humans to make collective action. This is strongly supported by Dumont et al. (2014), who suggested a wide range of relevant research focus areas directed towards enabling a transition to more resilient and sustainable agricultural and food systems, areas such as development of principles for systems design in various contexts, collective action initiatives, and interaction between different systems components. 
Scientific development and research goes strongly hand in hand with the teaching of students. Rickerl and Francis (2004) pointed to the importance of including multidimensional thinking, systems understanding, as well as ethical, social and ecological dimensions of agriculture and food systems. They developed approaches to letting the students direct their learning themselves (Francis, 2003), since they - as much as farmers and everybody else - need context relevant and specific learning. Tittonell (2013) outlined how courses around farming systems ecology were organized in a university setting in ten steps, exploring all inter-linkages between elements and whole systems analysis.

\section{Conclusion and Future Perspectives}

This article presents and discusses a range of options and challenges for better integration of animals into organic agricultural systems, aiming at synergy between the animals and the other functions and productions of the farm. In many parts of EU and elsewhere, policies have to a large extent encouraged commodity oriented and rather mono-cultural, large-scale organic agriculture more than focused on eco-functional integrity, diversification and resilience of agricultural systems. To intensify organic agriculture in alternative ways, through EFI with a focus on synergies and harmonies within the agricultural systems, and between agricultural, natural and social systems, profound structural and social changes have to be developed regarding current agricultural and food systems, including consumption patterns, and directions of knowledge generation and innovation. A key to bringing about such changes is our governance of agricultural and food systems, strategies such as engagements in nature conservation as part of forming agro-ecological farming systems, and forming social communities to contribute to local food systems. Animals can become valuable and relevant partners of such systems, and numerous studies of agricultural systems in many different contexts, demonstrate multiple synergies within the systems, which also benefit animals' health and welfare.

\section{Acknowledgements}

This article is among others inspired by project work in the EU-funded project SOLID (Agreement no. 266367; http://www.solidairy.eu/), and the Danida funded project ProGrOV (10-014-AU; $\mathrm{http} / /$ drp.dfcentre.com/project/productivity-and-growth-organic-value-chains-progrov). Peter Gordy is gratefully acknowledged for valuable language editorial suggestions to this article.

\section{References}

Alrøe, H. F., Vaarst, M., \& Kristensen, E. S. (2001). Does organic farming face distinctive livestock welfare issues? - A conceptual analysis. J.Envir.Agr. Ethics, 14(3), 275-299. http://dx.doi.org/10.1023/A:1012214317970

Amede, T., Geheb, K., \& Douthwaite, B. (2009). Enabling the uptake of livestock-water productivity interventions in the crop-livestock systems of sub-saharan Africa. The Rangeland Journal, 38, 223-230. http://dx.doi.org/10.1071/RJ09008

Anonymous. (2014). Organic Marketing Report. Academics Review. Retrieved from http://academicsreview.org/wp-content/uploads/2014/04/Academics-Review_Organic-Marketing-Report1.p df, p. 16.

Appleby, M. (2005). Sustainable agriculture is humane, humane agriculture is sustainable. J. Agr. Envir. Ethics, 18, 293-303. http://dx.doi.org/10.1007/s10806-005-1490-9

Araya, H., \& Edwards, S., (2006). The Tigray experience: A success story in sustainable agriculture. Third world network environment and development series 4 TWN: Penang, p. 45. Retrieved from http://www.twnside.org.sg/title/end/pdf/end04.pdf

Awada, L. (2011). Identifying needs. On-line presentation, 25 slides. Retrieved February 21, 2015, from http://www.oie.int/fileadmin/Home/eng/Support_to_OIE_Members/pdf/Ms.\%20Lina\%20Awada.pdf

Baars, T., Wagenaar, J. P., Padel, S., \& Lockeretz, W. (2004). The Role of Animals in Farming Systems: a Historical Perspective. In M. Vaarst, S. Roderick, V. Lund \& W. Lockeretz (Eds.), Animal health and welfare in organic agriculture (Chapter 2, pp. 13-28). Wallingford, UK: CABI Publishing. http://dx.doi.org/10.1079/9780851996684.0013

Bennedsgaard, T. W., Klaas, I. C., \& Vaarst, M. (2010). Reducing use of antimicrobials - Experiences from an intervention study in organic dairy herds in Denmark. Livest Sci, 131(2), 183-192. http://dx.doi.org/10.1016/j.livsci.2010.03.018

Bonaudo, T., Bendahan, A. B., Sabatier, R., Ryschawy, J., Bellon, S., Leger, F., ... Tichit, M. (2014). Agroecological principles for the redesign of integrated crop-livestock systems. European Journal of Agronomy, 57, 43-51. http://dx.doi.org/10.1016/j.eja.2013.09.010 
Bracke, M. B. M., \& Spoolder, H. A. M. (2013). Review of wallowing in pigs: implications for animal welfare. Animal Welfare, 20, 347-363.

Cabaret, J., Chylinski, C., \& Vaarst, M. (2014). The Freedoms and Capabilities of Farm Animals: How Can Organic Husbandry Fulfill Them? In S. Bellon \& S. Penvern (Eds.) Organic Farming, Prototype for Sustainable Agricultures (pp. 261-278). Springer Science og Business Media, Inc. http://dx.doi.org/10.1007/978-94-007-7927-3_14

Descheemaeker, K., Amede, T., \& Haileslassie, A., (2010). Improving water productivity in mixed crop-livestock farming systems of sub-Saharan Africa. Agricultural Water Management, 97, 579-586. http://dx.doi.org/10.1016/j.agwat.2009.11.012

Devendra, C., \& Thomas, D. (2002). Crop-animal interactions in mixed farming systems in Asia. Agricultural Systems, 71, 27-40. http://dx.doi.org/10.1016/S0308-521X(01)00042-7

Dumont, B., Fortun-Lamothe, L., Jouen, M., Thomas, M., \& Tichit, M. (2013). Prospects from agroecology and industrial ecology for animal production in the $21^{\text {st }}$ century. ANIMAL, 7(6), 1028-1043. http://dx.doi.org/10.1017/S1751731112002418

Dumont, B., Gonzáles-Garcia, E., Thomas, M., Fortun-Lamothe, L., Ducrot, C., Dourmad, J. Y., \& Tichit, M. (2014). Forty research issues for the redesign of animal production systems in the $21^{\text {st }}$ century. $A N I M A L$, 8(8), 1382-1393. http://dx.doi.org/10.1017/S1751731114001281

Döring, T. F., Vieweger, A., Pautasso, M., Vaarst, M., Finckh, M. R., \& Wolf, M. S. (2014). Resilience as a universal criterion of health. Journal of the Science of Food and Agriculture, 11. http://dx.doi.org/10.1002/jsfa.6539

Edwards, S., Egziabher, T. B. G., \& Araya, H, (2010). Successes and challenges in ecological agriculture. Experiences from Tigray, Ethiopia (p. 58). Food and Agriculture Organization of United Nations.

FAO. (2006). World Agriculture: towards 2030/2050. Interim report. Prospects for food, nutrition, agriculture and major commodity groups (p. 78). Rome: FAO.

FAO. (2011). Concepts, definitions and classifications surrounding livestock statistics. Retrieved from http://www.fao.org/economic/the-statistics-division-ess/methodology/methodology-systems/livestock-statis tics-concepts-definitions-and-classifications/ar/

FAO. (2013). Food outlook. Biannual report on global food markets (p. 139). Retrieved from http://www.fao.org/docrep/019/i3473e/i3473e.pdf

FAO. (2015). Coping with climate change - the roles of genetic resources for food and agriculture. Rome. p. 130.

Fraser, D. (2008). Understanding Animal Welfare. Science in its Cultural Context (p. 336). Oxford, UK: Wiley-Blackwell.

Funes-Monzote, F. R. (2008). Farming like we're here to stay. The mixed farming alternative for Cuba. Wageningen University, Ph.D.thesis, p. 211.

Gamborg, C., \& Sandøe, P. (2005). Sustainability in farm animal breeding. A review. Livest.Prod. Sci, 92(3), 221-32. http://dx.doi.org/10.1016/j.livprodsci.2004.08.010

Gliessman, S. (2006). Agroecology: The Ecology of Sustainable Food Systems (2nd ed, chapter 19: animals in agroecosystems).

González-García, E., Gourdine, J. L., Alexandre, G., Archiméde, H., \& Vaarst, M. (2012). The complex nature of mixed farming systems requires multidimensional actions supported by integrative research and development efforts. ANIMAL, 6, 763-777. http://dx.doi.org/10.1017/S1751731111001923

Haynes, R. P. (2008). Animal Welfare. Competing Conceptions and their Ethical Implications. Springer Science and Business Media, New York.

Hendriksen, M. K., \& James, H. S. (2005). The ethics of constrained choice: how the industrialization of agriculture impacts farming and farmer behaviour. J. Agr. Envir. Ethics, 18, 269-291. http://dx.doi.org/10.1007/s10806-005-0631-5

Hermansen J. E. (2003). Organic Livestock production systems and appropriate development in relation to public expectations. Livest. Prod. Sci., 80, 3-15. http://dx.doi.org/10.1016/S0301-6226(02)00313-5

Hilimaire, K. (2011). Integrated Crop/Livestock Agriculture in the United States: a review. J. Sust. Agr., 35(4), 376-393. http://dx.doi.org/10.1080/10440046.2011.562042 
IFOAM. (2005). Principles of Organic Agriculture Preamble. p. 4. Retrieved from http://www.ifoam.org/organic_facts/principles/pdfs/IFOAM_FS_Principles_forWebsite.pdf

Ivemeyer, S., Bell, N., Brinkmann, J., Cimer, K., Gratzer, E., Leeb, C., ... Vaarst, M. (2015). Farmers taking responsibility for herd health development - Stable Schools in research and advisory activities as a tool for dairy health and welfare planning in Europe (submitted manuscript).

Ivemeyer, S., Smolders, G., Brinkmann, J., Gratzer, E., Hansen, B., Henriksen, B. I. F., ... Walkenhorst, M. (2012). Impact of animal health and welfare planning on medicine use, herd health and production in European organic dairy farms. Livest Sci, 145(1-3), 63-72. http://dx.doi.org/10.1016/j.livsci.2011.12.023

Kiggundu, M., Kabi, F., Vaarst, M., Nalubwama, S., \& Odhong, C. (2015). Management and use of dairy cattle feed resources on smallholder certified organic pineapple farms in Central Uganda. Journal of Agriculture and Environment for International Development (in press).

Kongsted, A. G., Horsted, K., \& Hermansen, J. (2013). Free-range pigs foraging on Jerusalem artichokes (Helianthus tuberosus L.) - Effect of feeding strategy on growth, feed conversion and animal behavior. Acta Agr. Scand. Section A - Animal Science, 63(2), 76-83.

Lemaire, G., Franzluebbers, A., de Faccio Carvalho, P. C., \& Dedieu, B. (2014). Integrated crop-livestock systems: Strategies to achieve synergy between agricultural production and environmental quality. Agriculture, Ecosystems and Environment, 190, 4-8. http://dx.doi.org/10.1016/j.agee.2013.08.009

Lund, V. (2002) Ethics and animal welfare in organic animal husbandry - an interdisciplinary approach. Ph.D.thesis, Swedish University of Agricultural Sciences; Acta Universitatis Agriculturae Sueciae Veterinariae 137, Skara, Sweden.

Lund, V. (2006) Natural living-a precondition for animal welfare in organic farming. Livestock Science, 100, 71-83. http://dx.doi.org/10.1016/j.livprodsci.2005.08.005

Lund, V., Anthony, R., \& Röcklinsberg, H. (2004). The ethical contract as a tool in organic animal husbandry. $J$. Agr. Env. Ethics, 17, 23-49. http://dx.doi.org/10.1023/B:JAGE.0000010843.60352.65

Lund, V., \& Olsson, A. S. (2006). Animal agriculture: Symbiosis, culture, or ethical conflict? J. Agr. Envir. Ethics, 19, 47-56. http://dx.doi.org/10.1007/s10806-005-4378-9

MacMillan, T., \& Benton, T. G. (2014). Engage farmers in research. Nature, 508, 25-27. http://dx.doi.org/10.1038/509025a

McDermott, J. J., Staal, S. J., Freeman, H. A., Herrero, M., \& Van de Steeg, J. A. (2010). Sustaining intensification of smallholder liverstock systems in the tropics. Livestock Science, 130, 95-109. http://dx.doi.org/10.1016/j.livsci.2010.02.014

Mogensen, L. (2004). Organic milk production based entirely on home-grown feed. Ph. D thesis. The Royal Veterinary and Agricultural University, Copenhagen.

Molden, D., Oweis, T., Seduto, P., Hanja, M. A., \& Kijne, J. (2010). Improving agricultural water productivity between optimism and caution. Agricultural Water Management, 97, 528-535. http://dx.doi.org/10.1016/j.agwat.2009.03.023

Moraine, M., Duru, M., Nicholas, P., Leterme, P., \& Therond, O. (2014). Farming systems design for innovative $\begin{array}{lllll}\text { crop-livestock integration in } & \text { Europe. }\end{array}$ http://dx.doi.org/10.1017/S1751731114001189

Muwanga, S. N., Mugisha, A., \& Vaarst, M. (2010). Organic livestock production in Uganda: Potentials, challenges and prospect. Tropical Animal Health and Production,

Nalubwama, S., Vaarst, M., Kabi, F., Kiggundu, M., Bagamba, F., Odhong, C., ... Halberg, N. (2014a). Challenges and prospects of integrating livestock into smallholder organic pineapple production in Uganda. Livestock Research for Rural Development, 6, Article \#113. Retrieved from http://www.lrrd.org/lrrd26/6/nalu26113.htm

Nalubwama, S., Vaarst, M., Kabi, F., \& Kiggundu, M. (2014b). Animal Husbandary Practices Of Smallholder Organic Farmers In Uganda: Challenges And Future Prospects Animal Husbandary Practices Of Smallholder Organic Farmers In Uganda: Challenges And Future Prospects. In G. Rahmann \& U. Aksoy (Eds.) Building Organic Bridges, Johann Heinrich von Thünen-Institut, Braunschweig, Germany, 4, Thuenen Report, no. 20, pp. 1123-1126.

Niggli, U., Slabe, A., Schmid, O., Halberg, N., \& Schlüter, M. (2008). Vision for an Organic Food and Farming Research Agenda to 2015. Organic Knowledge for the future. IFOAM EU / FiBL, Switzerland. p. 44. 
Odhong, C., Wahome, R. G., Vaarst, M., Kiggundu, M., Nalubwama, S., Halberg, N., \& Githigia, S. (2014). Challenges of conversion to organic dairy production and prospects of future development in integrated smallholder farms in Kenya. Livestock Research for Rural Development, 26, Article \#125. Retrieved January 5, 2015, from http://www.lrrd.org/lrrd26/7/odho26125.html

Padel, S., Vaarst, M., \& Zaraliz, K. (2015). Supporting innovation in organic agriculture: A European perspective using experience from the SOLID project (ibid).

Peden, D., Taddesse, G., \& Misra, A. (2007). Water and livestock for human development. In D. Molden (Ed.) Water for food, water for life: a comprehensive assessment of water management in agriculture (pp. 485-515). Interantional Water Management Institution, Colombo, Sri Lanka. Earthscan, London.

Pedersen, H. L., Olsen, A., Horsted, K., Korsgaard, M., \& Pedersen, B. (2004). Combined production of broilers and fruits. ECO-FRU-VIT. $11^{\text {th }}$ International Conference on cultivation technique and phytopathological problems in organic fruit growing, Weinsberg: 131-136.

Powell, J. M., Pearson, R. A., \& Hiernaux, P. H., (2004). Crop-livestock interactions in the West African drylands. Agronomy Journal, 96, 469-483. http://dx.doi.org/10.2134/agronj2004.0469

Rauw, W. M., Kanis, E., Noordhuzen-Stassen, E. N., \& Grommers, F. J. (1998). Undesirable side effects of selection for high production efficiency in farm animals: a review. Livestock Production Science, 56, 15-33. http://dx.doi.org/10.1016/S0301-6226(98)00147-X

Rickerl, D., \& Francis, C. (2004). Multidimensional thinking: a prerequisite to agroecology. In: Agroecosystems Analaysis. Agronomy Monograph no. 43. American Society of Agronomy, Crop Science Society of America, Soil Science Society of America, 677 S Segoe Rd. Madison, WI 53711, USA. p. 17.

Rockström, J. W., Steffen, K., Noone, Å., Persson, F. S., Chapin, Iii, E., Lambin, T. M., ...Foley, J. (2009). Planetary boundaries:exploring the safe operating space for humanity. Ecology and Society, 14(2), 32.

Rubaire-Akiiki, C., Okello-Onen, J., Musanga, D., Kabagambe, E. K., Vaarst, M., Okello, D., ... Mwayi, M. T. (2006). Effect of agro-ecological zone and grazing system on incidence of East Coast Fever in calves in Mbale and Sironko Districts of Eastern Uganda. Preventive Veterinary Medicine, 75, 251-266. http://dx.doi.org/10.1016/j.prevetmed.2006.04.015

Schader, C., Muller, A., \& Scialabba, N. E. -H. (2013). Sustainability and organic livestock modelleing (SOL-m). Impacts of a global upscaling of low-input and organic livestock production. Preliminary results. Natural Resources Management and Environmental Department, FAO, Rome, Itly. p. 10. http://www.fao.org/fileadmin/templates/nr/sustainability_pathways/docs/SOL-m_summary_Final.pdf

Schader, C., Muller, A., Scialabba, N. E.-H., Hecht, J., \& Stolze, M. (2014). Comparing global and product-based LCA perspectives on environmental impacts of low-concentrate ruminant production. In: Schenck, R. \& Huizenga, D. (eds) 2014. Proceedings of the $9^{\text {th }}$ International Conference on Life Cycle Assessment in the Agro-Food Sector, 8-10 October 2014, San Francisco, ACLCA, Vashon, WA, USA, 1203-1209. http://lcafood2014.org/papers/209.pdf

Steinfeld, H., Gerber, P., Wassenaar, T., Castel, V., Rosales, M., \& De Haan, C. (2006). Livestock's long shadow - environmental issues and options (p. 390). Rome, Italy: FAO.

Sundrum, A., Padel, S., Arsenos, G., Henriksen, B., Walkenhorst, M., \& Vaarst, M. (2006). Current and proposed EU legislation on organic livestock production, with a focus on animal health, welfare and food safety: A review', I Future perspectives for animal health on organic farms: Main findings, conclusions and recommendations from the SAFO network, s. 75-90.

Tcharntke, T., Clough, Y., Wanger, T. C., Jackson, L., Motzke, I., Perfecto, I, ... Whitbread, A. (2012). Global food security, biodiversity conservation and the future of agricultural intensification. Biological Conservation, 151, 53-59. http://dx.doi.org/10.1016/j.biocon.2012.01.068

Tichit, M., Puillet, L., Sabatier, R., \& Teillard, F. (2011). Multicriteria performance and sustainability in livestock farming systems: functional diversity matters. Livest. Sci., 139, 161-171. http://dx.doi.org/10.1016/j.livsci.2011.03.006

Tittonell, P. (2013). Farming Systems Ecology. Towards ecological intensification of world agriculture. Inaugural lecture upon taking up the position of Chair in Farming Systems Ecology at Wageningen University. Wageningen, N1, p. 40.

Vaarst, M. (2007). Participatory Common Learning in Groups of Dairy Farmers in Uganda (FFS approach) and Danish Stable Schools. DJF Report 78, Aarhus University. p. 72. 
Vaarst, M., Alban, L., Mogensen, L., Thamsborg, S. M., \& Kristensen, E. S. (2001). Health and Welfare in Danish dairy cattle in transition to organic production: problems, priorities and perspectives. J. Agric. Environ. Ethics, 14(4), 367-390. http://dx.doi.org/10.1023/A:1013060304868

Vaarst, M., Gratzer, E., Walkenhorst, M., Ivemeyer, S., Jan Brinkman, S., March, L. K., ... Mejdell, C. M. (2010). Farmer groups for animal health and welfare planning in European organic dairy herds. Proceedings of the 9th European IFSA Conference, Vienna, 4.-7. July, 2010, 683-691, Retrieved from http://ifsa.boku.ac.at/cms/fileadmin/Proceeding2010/2010_WS1.8_Vaarst.pdf

Vaarst, M., Nissen, T. B., Ostergaard, S., Klaas, I. C., Bennedsgaard, T. W., \& Christensen, J. (2007). Danish stable schools for experiential common learning in groups of organic dairy farmers. J Dairy Sci, 90(5), 2543-2554. http://dx.doi.org/10.3168/jds.2006-607

Vaarst, M., Roderick, S., Lund, V., Lockeretz, W., \& Hovi, M. (2004a). Organic principles and values: the Framework for Organic Animal Husbandry. In M. Vaarst, S. Roderick, V. Lund \& W. Lockeretz (Eds.), Animal health and welfare in organic agriculture (Chapter 1, pp. 1-12). Wallingford, UK: CABI Publishing. http://dx.doi.org/10.1079/9780851996684.0001

Vaarst, M., Roderick, S., Lund, V., \& Lockeretz, W. (2004b). Combining ethological thinking and epidemiological knowledge to enhance the naturalness of organic livestock systems. In BGS/AAB/COR 2004 Conference, BGS Occasional Symposium No. 37, Organic Farming, 87-91.

Vaarst, M., Roderick, S., Byarugaba, D. K., Kobayashi, S., Rubaire-Akiiki, C., \& Karreman, H. J. (2006). Sustainable veterinary medical practices in organic farming: A global perspective. In N. Halberg, H. F. Alrøe, M. T. Knudsen \& E. S. Kristensen (Eds.), Global Development of Organic Agriculture (pp. 241-276). Challenges and Prospects, CABI Publishings. http://dx.doi.org/10.1079/9781845930783.0241

Vaarst, M., Roderick, S., Smolders, G., Leeb, C., Walkenhorst, M., Winckler, C., ... Nicholas, P. (2011a). The dialogue with farmers. ANIPLAN Final Report, 64-79.

Vaarst, M., Winckler, C., Roderick, S., Smolders, G., Ivemeyer, S., Brinkmann, J., ... Huber, J. (2011b). Animal health and welfare planning in organic dairy cattle farms. Open Vet Journal 5 (Suppl 1: M5), 19-25.

Vanlauwe, B., Coyne, D., Gockowski, J., Hauser, S., Huising, J., Masso, C., ... Van Aste, P. (2014). Sustainable intensification and the African smallholder farmer. Current Opinion in Environmental Sustainability, 8, 15-22. http://dx.doi.org/10.1016/j.cosust.2014.06.001

Verhoog, H., Lund, V., \& Alrøe, H. F. (2004). Animal Welfare, Ethics and Organic Farming. In M. Vaarst, S. Roderick, V. Lund \& W. Lockeretz (Eds.), Animal health and welfare in organic agriculture (Chapter 5, pp. 73-94) Wallingford, UK: CABI Publishing. http://dx.doi.org/10.1079/9780851996684.0073

Verhoog, H., Lammerts van Bueren, E. T., Matze, M., \& Baars, T. (2007). The value of 'naturalness' in organic agriculture. NJAS - Wageningen Journal of Life Sciences, 54(4), 333-345. http://dx.doi.org/10.1016/S1573-5214(07)80007-8

Waiblinger, S., Baumgartner, J., Kiley-Worthington, M., \& Niebuhr, K. (2004). Applied Ethology: the Basis for Improved Animal Welfare in Organic Farming. In M. Vaarst, S. Roderick, V. Lund \& W. Lockeretz (Eds.), Animal health and welfare in organic agriculture (Chapter 7, pp. 117-161). Wallingford, UK: CABI Publishing. http://dx.doi.org/10.1079/9780851996684.0117

Willer, H., \& Lernoud, J. (2015). The world of organic agriculture - statistics and emerging trends 2015. FiBL -IFOAM Report. Research Institute of Organic Agriculture (FiBL), Frick, and IFOAM - Organics International, Bonn, p. 306.

\section{Copyrights}

Copyright for this article is retained by the author(s), with first publication rights granted to the journal.

This is an open-access article distributed under the terms and conditions of the Creative Commons Attribution license (http://creativecommons.org/licenses/by/3.0/). 